\title{
Extraction and evaluation of tannin from green coconut mesocarp
}

\section{Extração e avaliação do tanino do epicarpo e mesocarpo do coco verde}

\author{
Fernanda Lago Morbeck ${ }^{1}$, Roberto Carlos Costa Lelis ${ }^{1}$, \\ Maria Vanessa Egger Schueler ${ }^{1}$, Wanessa Aparecida Santos ${ }^{1}$, \\ Danielle Affonso Sampaio ${ }^{1}$, Bruno Couto da Silva ${ }^{1}$, \\ Rayssa de Medeiros Morais ${ }^{1}$, Gregório Mateus Santana ${ }^{1}$
}

\footnotetext{
${ }^{1}$ Federal Rural University of Rio de Janeiro - LPF/IF/UFRRJ, BR 465, km 07, 23890-000, Seropédica, Rio de Janeiro, Brazil.

e-mail: fernanda@morbeck.net, lelis@ufrrj.br, vanessa.egger@live.com, wanessasantosrj@hotmail.com, danitheu@gmail.com, brunoengf@gmail.com, rayssaengflorestal@gmail.com, gregorioengflorestal@gmail.com
}

\begin{abstract}
The development of alternatives for reuse of coconut shell allows inadequate solid residues disposal reduction and provides a novelty option close to the production sites. This paper aims to evaluate the tannin extraction potential of the green coconut mesocarp, as well as its adhesive capacity. Tannin extraction was performed with sodium sulfite diluted in water at $0 \%, 1 \%, 5 \%$ and $8 \%$ concentrations. It was observed which extraction resulted in better yield and characteristics to be used as an adhesive agent. The concentration of sodium sulfite at $5 \%$ allowed higher yields of tannin extraction. When compared to phenol formaldehyde, the tannin had similar adhesive characteristics such as $153.84 \mathrm{cp}$ viscosity and $54.57 \%$ solid content. For the FTIR spectroscopy analysis, dry samples of the coconut mesocarp were used. The peaks observed in the infrared spectrum of the green coconut mesocarp are characteristic of tannins found in biomass, presenting desirable chemical characteristics to be used as an adhesive agent. The coconut mesocarp is a material with potential for tannin extraction, making it suitable to be used in the gluing of panels.
\end{abstract}

Keywords: Cocos nucifera, adhesives, residues.

\section{RESUMO}

O desenvolvimento de alternativas para o aproveitamento da casca de coco possibilita a redução da disposição inadequada de resíduos sólidos e proporciona uma nova opção de rendimento junto aos locais de produção. O presente trabalho tem como objetivo avaliar o potencial de extração de taninos do mesocarpo de coco verde e sua capacidade adesiva. A extração do tanino foi feita em água com adição de sulfito de sódio a $0 \%, 1 \%, 5 \%$ e $8 \%$. Em seguida, observou-se qual dessas extrações demonstrou melhores rendimentos e características para ser usado como agente adesivo. A concentração de sulfito de sódio a 5\% possibilitou maior rendimento na extração de taninos. Quando comparado com fenol-formaldeído, o tanino apresentou características adesivas similares como viscosidade $153,84 \mathrm{cp}$ e teor de sólido 54,57\%. Para a análise de espectroscopia FT-IR foram utilizadas amostras secas do mesocarpo do coco. Os picos observados no espectro de infravermelho do mesocarpo do coco verde são característicos de taninos encontrados em biomassa, apresentando características químicas desejáveis para ser utilizado como agente adesivo. O mesocarpo do coco é um material com potencial para extração de taninos a ser empregados na colagem de painéis.

Palavras-chave: Cocos nucifera, adesivos, resíduos.

\section{INTRODUCTION}

Renewable resources can be used to replace phenolic compounds from the petrochemical sector. Examples of such resources are lignin residue derived from pulping, tannins from bark, wood of some forest species and products derived from the carbonization of forest biomass [1]. Among these options, tannins present the most desirable qualities for such substitution, more specifically, condensable tannins [2]. 
Tannins are polyphenols of high molecular weight, found in several parts of plants, bark, root, wood and fruits. They easily react with formaldehyde and thus may be used as source of adhesive, while mitigating issues with agricultural market residues [1].

According to the Brazilian national solid waste policy, all farmers must elaborate a solid waste management plan, describing how the waste will be correctly disposed of. This led to an increase in the use of non-timber forest residues; as result, those residues became alternatives as raw material in manufacture of different forest-based products, such as tannin [3].

The coconut fruit mesocarp is considered a form of waste, since its monoculture is destined to the use of coconut water and its pulp. Coconut residue is a noble material that can be used in different ways, ranging from the upholstery fabric for automobiles manufacture as well as for the extraction of tannin [4].

Considering the increasing demand for tannins, the search for renewable sources and the need to generate alternatives that give destiny or add value to the green coconut shell, the present work aimed to chemically characterize the green coconut mesocarp by FT-IR spectroscopy and evaluation of its extracts properties, comparing them to the synthetic phenol-formaldehyde (PF) adhesive as well as its potential as an adhesive.

\section{MATERIAL AND METHODS}

\subsection{Material obtention}

Mesocarp of green coconut (Cocos nucífera) collected in the city of Itaguaí (Rio de Janeiro, Brazil) was used as raw material. The material was air dried, fragmented in hammer mill, sieved and stored. This material was used in chemical analysis by infrared spectroscopy and tannin extraction.

\subsection{Chemical analysis of mesocarp by Fourier transform infrared spectroscopy (FT-IR)}

Infrared spectroscopy is a technique used for both characterization and qualitative analysis of vegetal fibers. According to SOCRATES [5] the infrared spectrum of any substance is used to find out the frequencies related to a determined group or chemical bond. The usage of Fourier transform for instrumental analysis of infrared spectroscopy has enabled analytical studies of solid plants and their respective components [6].

For the FT-IR spectroscopy analysis, dry samples of the coconut mesocarp were used. The samples were milled in ball mill until the average particle acquired a dust-like granulometry, and dried using a lyophilizer (TERRONI®) for complete dehydration of the material.

The spectra were on a VARIAN 640-IR FT-IR spectrometer set in transmittance mode with a $4 \mathrm{~cm}^{-1}$ resolution, 128 scans, $4000-400 \mathrm{~cm}^{-1}$ spectral range.

\subsection{Tannin extraction}

Tannin extraction was carried out with water and water with addition of different concentrations of sodium sulphite $\left(\mathrm{Na}_{2} \mathrm{SO}_{3}\right)$. giving 4 treatments (Table 1). For each extraction, $10 \mathrm{~g}$ of mesocarp were placed in a flask with $150 \mathrm{~mL}$ distilled water under reflux for 2 hours at $80^{\circ} \mathrm{C}$. After extraction, the material was vacuum filtered. For each treatment, five replicates were performed.

Table 1: Treatments used for extracting tannins from the green coconut mesocarp.

\begin{tabular}{c|c}
\hline TREATMENTS & EXTRACTIONS \\
\hline $\mathrm{T} 1$ & $\mathrm{H}_{2} \mathrm{O}$ \\
\hline $\mathrm{T} 2$ & $\mathrm{H}_{2} \mathrm{O}+1 \% \mathrm{Na}_{2} \mathrm{SO}_{3}$ \\
\hline $\mathrm{T} 3$ & $\mathrm{H}_{2} \mathrm{O}+5 \% \mathrm{Na}_{2} \mathrm{SO}_{3}$ \\
\hline $\mathrm{T} 4$ & $\mathrm{H}_{2} \mathrm{O}+8 \% \mathrm{Na}_{2} \mathrm{SO}_{3}$ \\
\hline
\end{tabular}

Salt percentage was calculated based in coconut mesocarp dry mass

\subsection{Evaluation of the extracts properties}


For each treatment, extractives contents, content of polyphenols condensed by the Stiasny method (number of Stiasny - NS), tannin content and non - tannin content were determined. After each extraction, a $25 \mathrm{~mL}$ aliquot of the filtrate was separated to determine the extractive content, according to FERREIRA et al. [7]. The contents of condensed polyphenols were calculated by Stiasny's reaction [8]. Based on the content of polyphenols and extractive contents, the percentage of tannins was calculated. The treatment that obtained the best yield in tannins was chosen for autoclaving.

\subsection{Autoclave extraction}

Tannin extraction was performed in an autoclave at $80{ }^{\circ} \mathrm{C}$ for a period of 2 hours. The mesocarp: liquor ratio was $1: 15$. After each extraction, the material was filtered and oven-dried at $103 \pm 2{ }^{\circ} \mathrm{C}$. Subsequently, the material was oven-dried at $60{ }^{\circ} \mathrm{C}$ and milled until the average particle size was of 200 mesh for subsequent adhesive production.

\subsection{Determination of adhesive properties}

The adhesive properties evaluated were: viscosity, solids content, gel time and $\mathrm{pH}$. Viscosity was determined using a Ford Cup (Universal) type viscometer and following the parameters as ASTM D-1200 [9]. The solids content was calculated according to BRITO [10]. Gel time was obtained using 10g adhesive samples from each treatment, placed in test tubes $15 \mathrm{~cm}$ in height and $2 \mathrm{~cm}$ in diameter. The rod-tube assembly was dipped in a glycerin bath at $130{ }^{\circ} \mathrm{C}$. With the aid of the stick, the liquid was constantly stirred with vertical movement, as a function of the increase in the resistance of the adhesive upon reaching the "gel phase". The gelatinization time for each treatment was that between immersion of the tube in the glycerin and the moment the sample hardened. The $\mathrm{pH}$ of the tannic extract solution was determined by digital $\mathrm{pH}$ meter at room temperature. The $\mathrm{pH}$ value was recorded after a time of 4 minutes of contact of the electrode with the solution.

The phenol-formaldehyde resin and its modifications with green body mesocarp tannic extracts were also evaluated for gel time, viscosity, $\mathrm{pH}$ and solids content. The methodology followed the above. The FF resin was modified by replacing part of the resin with a $50 \%$ solids tannic extract solution in the proportions of $10 \%, 20 \%$ and $30 \%(90: 10,80: 20,70: 30)$. The determination of the gel time of the FF resin and its modifications with coconut mesocarp tannins was carried out in a ratio of $1: 1$, using $10 \mathrm{~g}$ of solution (base dry mass of solids) and $10 \mathrm{~mL}$ of formaldehyde, which was the agent hardener. The solids content and $\mathrm{pH}$ were evaluated according to the previous methodology

\subsection{Statistical Analyses}

For statistical analyzes, characterization and quantification of the tannic extract performed using completely randomized design with five replicates, at $5 \%$ probability, evaluating the effect of the sodium sulfite content on the tannin yield, based on the statistical significance of the coefficients, ANOVA and Tukey.

\section{RESULTS AND DISCUSSIONS}

\subsection{Chemical analysis of mesocarp by Fourier transform infrared spectroscopy (FT-IR)}

Figure 1 shows the infrared spectrum of the green coconut mesocarp tannin. 


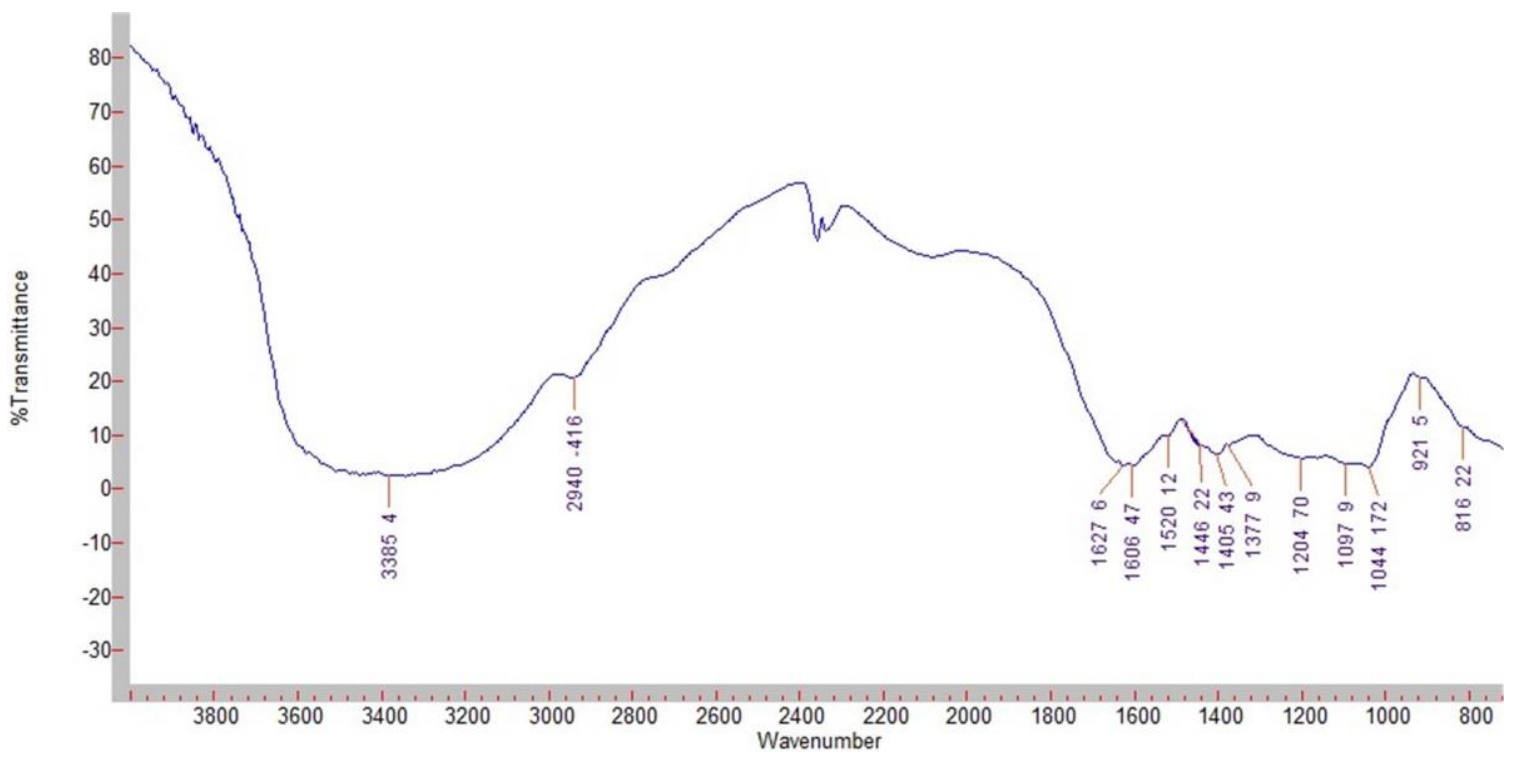

Figure 1: FT-IR spectrum of green coconut mesocarp.

Infrared analysis provided data that may help to understand the sample chemically. The absorption peak at $\sim 3400 \mathrm{~cm}^{-1}$ evidences stretching of hydroxyl groups $(\mathrm{O}-\mathrm{H})$ in aliphatic and phenolic structures [11]. This group presents a band in the region between 3500 and $3000 \mathrm{~cm}^{-1}$, referring to the vibrations of the $\mathrm{OH}$ group. This band is wider in the tannin and adhesive spectra due to hydroxyl- rich structures present in the aromatic rings [12].

At $2930 \mathrm{~cm}^{-1}$ a weak band related to the axial deformation of the methylene $\mathrm{CH}$ bond is present, different from that is observed in industrial adhesives, since this band presents itself a little more intense due to $\mathrm{HCH}$ groups formed with furfuryl alcohol linkage to phenolic rings of tannins [13]. This band also indicates predominant bonds that bind the aromatic rings of the tannins, and may represent the formation of the resin $[13 ; 12]$.

At $1600 \mathrm{~cm}^{-1}$ and $1620 \mathrm{~cm}^{-1}, \mathrm{C}=\mathrm{C}$ stretch of aromatic rings can be found [14, 15]. Axial deformation of the $\mathrm{C}=\mathrm{C}$ bond of the aromatic ring occurs in those linkages and indicate high number of interflavonoid bonds [16]. The peak at $1520 \mathrm{~cm}^{-1}$ refers to the stretching of C-C and C-O [17].

The peak at $1446 \mathrm{~cm}^{-1}$ refers to the stretching of aromatic ring vibrations [18]. The one at $\sim 1400 \mathrm{~cm}^{-1}$ refers to the $\mathrm{C}-\mathrm{OH}$ folding in the plane, are widened due to the axial deformation of the $\mathrm{C}=\mathrm{C}$ bond in aromatic rings [19]. Upon checking an adhesive IR spectrum, the band contained in the range of $\sim 1450$ to $1400 \mathrm{~cm}^{-1}$ disappears. According to ARANGUREN et al. [20], the increase of the substituent rings causes a reduction of these bands, which suggests the occurrence of cross-linking reactions between the components (tannin and hardener).

In $1370 \mathrm{~cm}^{-1}$, bending of aromatic groups is observed [21], whereas at $1204 \mathrm{~cm}^{-1}, \mathrm{C}-\mathrm{O}$ stretching of C$\mathrm{OH}$ bonds can be identified [22]. The peak at $1097 \mathrm{~cm}^{-1}$ is attributed to aromatic $\mathrm{C}-\mathrm{H}$ folding in the plane [18].

At $1040 \mathrm{~cm}^{-1}$, the symmetrical CO stretch [23] is identified, while the peaks at $816 \mathrm{~cm}^{-1}$ and at $\sim 921$ $\mathrm{cm}^{-1}$ are attributed to "out-of-plane" aromatic CH bending [24,13] and the para-substituted aromatic ring and tetrasubstituted 1,2,3 and 4, respectively. That confirms the formation of the adhesive by condensation with the furfuryl alcohol molecule. CARNEIRO et al. [25] state that the free C6 and / or C8 positions of the flavonoid units form the reactive sites of the tannin. The peaks observed in the FTIR spectrum of the green coconut mesocarp are characteristic of tannins found in biomass [26], presenting desirable chemical characteristics to be used as an adhesive agent.

\subsection{Evaluation of the mesocarp extraction with water and different concentrations of sodium sulfite}

Table 2 shows the results of the average values obtained for the properties of the extracts of the coconut mesocarp extracted with water and water under additions of different percentages of sodium sulfite $\left(\mathrm{Na}_{2} \mathrm{SO}_{3}\right)$ concentrations. 
Table 2: Mean values of extractive contents, number of Stiasny, tannin and non-tannins of the coconut mesocarp, after extraction with water and different concentrations of sodium sulfite.

\begin{tabular}{c|c|c|c|c}
\hline TREATMENTS & EXTRACTIVES (\%) & STIASNY INDEX (\%) & TANNINS (\%) & NON-TANNINS (\%) \\
\hline$\left(\mathrm{H}_{2} \mathrm{O}\right)$ & $6.08 \mathrm{~b}$ & $24.83 \mathrm{a}$ & $1.53 \mathrm{~b}$ & $4.54 \mathrm{a}$ \\
\hline$\left(\mathrm{H}_{2} \mathrm{O}+1 \% \mathrm{Na}_{2} \mathrm{SO}_{3}\right)$ & $9.26 \mathrm{~b}$ & $28.03 \mathrm{a}$ & $2.56 \mathrm{~b}$ & $6.70 \mathrm{a}$ \\
\hline$\left(\mathrm{H}_{2} \mathrm{O}+5 \% \mathrm{Na}_{2} \mathrm{SO}_{3}\right)$ & $19.22 \mathrm{a}$ & $18.41 \mathrm{a}$ & $3.37 \mathrm{a}$ & $15.85 \mathrm{a}$ \\
\hline$\left(\mathrm{H}_{2} \mathrm{O}+8 \% \mathrm{Na}_{2} \mathrm{SO}_{3}\right)$ & $4.40 \mathrm{~b}$ & $27.08 \mathrm{a}$ & $1.2 \mathrm{~b}$ & $3.21 \mathrm{a}$ \\
\hline
\end{tabular}

Means followed by same letters do not differ by Tukey test $(\mathrm{P}>0,05)$.

The initial parameter in the characterization of substances found in the bark is the yield in extractives, because it makes possible to define the treatment to be used based on higher productivity and the most effective way of obtaining these extractives [27]. The different percentages of sodium sulfite $\left(\mathrm{Na}_{2} \mathrm{SO}_{3}\right)$ resulted in a change in yield values in total solids(extractive). The treatment with the addition of 5\% sodium sulphite presented the highest extractive value and was statistically superior to the other treatments. The effect of the treatments on extractive removal of the coconut shell was significant in the conditions of the experiment.

The Stiasny index (SI) expresses the polyphenol content in the extract. The results obtained for the coconut mesocarp indicated that the treatment with the addition of $1 \%$ of sodium sulfite favored a greater solubilization of polyphenols, presenting the highest value of SI, but the ANOVA performed to evaluate the variance between the number of Stiasny, according to the different treatments of the extraction, shows that there was no significant difference between the means of the treatments (Table 2). The values found for the Stiasny index show the potential of the coconut mesocarp as a source of condensable polyphenols for woodbased adhesives production. PING et al. [13] defined the Stiasny index as an indicator of the polyphenol extracts purity. PIZZI and MITTAL [1] stated that SI is a parameter that indicates the ability of extractives to react with formaldehyde in the preparation of adhesives.

Tannin extraction from plant species is an important step, since the tannins during extraction may undergo variations or rearrangements in their properties and structure. The quality of the tannins varies, on a large scale, with the type of extraction employed; Therefore, the extraction conditions must be standardized and optimized, aiming the production of extracts with properties adjusted to the synthesis of adhesives [28]. The percentage of tannin varies according to species and substance used in the extraction. When tannins are extracted, several non-tannic components are also extracted. Therefore, when extracting a family of compounds with a specific type of solvent, other types of compounds are extracted together [29].

According to the results found in the statistical analysis, 5\% sodium sulphite obtained better yield in the tannic extraction of the coconut mesocarp when compared to water and other concentrations. The results obtained in relation to tannin values (Table 2) are in accordance with the literature, which states that condensed tannins can reach a range of 2 to $40 \%$ of the dry mass of the bark of plant species [30].

BRÍGIDA and MORSYLEIDE [31] obtained tannins content of $6.03 \%$ extracting coconut husk with solely hot water, higher than those found in this paper. It was observed that the increase in the percentage of extracting salt (sodium sulfite) to $5 \%$ led to an increase in tannin yield. This agrees with what was suggested by GONÇALVES et al. [30] and PIZZI and MITTAL [1], who showed that the higher the extractor percentage, the greater the solubility of sugars, amino acids and pectins, thus increasing tannins water solubility.

CARVALHO et al. [32] recommended extraction with sodium sulfite at $5 \%$ in an experiment with Pinus caribaea var. bahamensis, as high yields of tannins with a low percentage of non-tannins were obtained when compared to treatments with 8 and $10 \%$ of sodium sulfite. For VITAL et al. [33], 4.5\% sodium sulphite was recommended to obtain tannins from Eucalypus grandis peel, since it presented higher yield.

Studies conducted by FERREIRA et al. [7] evaluated the yield of the tannin content from bark of four pinus species and verified that the tannin extraction with distilled water with $5 \%$ of sodium sulfite added to the bark of Pinus oocarpa allowed higher yields of tannins. VIEIRA et al. [27] also observed for the bark of Pinus oocarpa when testing eight forms of tannin extraction, investigating the usage of bark tannins as adhesive for wood glue, that the extraction with $5 \%$ of sodium sulfite indicated higher tannin yield, being used later to make the tannin-formaldehyde adhesive. 
Regarding percentages of non-tannins, the lowest value of non-tannins was found in the $8 \%$ sodium sulfite water extraction, however, no significant differences were observed when compared to water extraction and other treatments. According to VIEIRA et al. [27] non-tannins correspond to the fraction of sugars and other non-phenolic extractives present in the bark extracts, and can negatively influence the quality of the adhesive.

\subsection{Evaluation of the properties of polyphenols and adhesive agents}

Mean values of coconut mesocarp tannin extracted with 5\% sodium sulfite and the industrial phenol formaldehyde synthetic adhesive can be observed in Table 3 for comparison and evaluation of the viability of the tannin extract in question.

Table 3: Tannin and Phenol-formaldehyde adhesive properties.

\begin{tabular}{c|c|c}
\hline PROPERTIES & TANNIN & PHENOL-FORMALDEHYDE \\
\hline $\mathrm{pH}$ & 3.97 & 12.48 \\
\hline Viscosity (cp) & 153.84 & 197.74 \\
\hline Solids content (\%) & 54.57 & 46.86 \\
\hline Gel time (mim) & $>30$ & $>30$ \\
\hline
\end{tabular}

Physical-chemical characteristics of the adhesive such as $\mathrm{pH}$, viscosity, gel time and solids content directly influence the adhesive cure time, which is related to the efficiency wood panels manufactory, since a decrease in production costs in panels made with adhesive occurs, of which cure time is low [34].

The $\mathrm{pH}$ range between tannin and phenol formaldehyde is very wide and distinct, where each has a characteristic. The coconut tannin presents an acidic $\mathrm{pH}$ value, which is already a characteristic of the tannic extracts. MORI et al. [29] found pH values below 5 for eucalyptus and black wattle tannin adhesives. Phenol formaldehyde has an alkaline (basic) $\mathrm{pH}$. The $\mathrm{pH}$ is an important factor during the bonding process, since it can interfere with the curing process of a resin [35], besides the fact that the $\mathrm{pH}$ in the adhesive does not have a value below 2.5, and doesn't exceed 11, as this may result in fiber degradation [36]. The $\mathrm{pH}$ value of coconut tannin was within the ideal range for use.

The viscosity values of the tannin compared to phenol formaldehyde were quite close. When the extract is the base of sulphites, the hydrolysis of carbohydrates, which have a relatively high molecular weight hydrocolloid gums, and the disruption of the interflavonoid (C4-C6 or C4-C8) bonds of the polymer units of the tannins occurs [1]. The presence of these high molecular weight gums is responsible for the high viscosity characteristic of the tannic extract. The viscosity is an important quantity for the adhesive, because when low it results in better spread on the surface of the wood, due to the high fluidity, contributing for the greater penetration of the adhesive and its absorption by the wood. High viscosity values can result in a weak glue line, with insufficient amount of adhesive in the glue line, thus impairing the adhesive distribution capacity, wetting and adhesion [37]. A viscosity value higher than 1500 centipoises (cp) is considered high and harmful [10]. Considering the viscosity data, the tannic extract presented excellent value for use in panels, demonstrating feasibility to cover the surfaces of the particles, thus influencing the dispersion of the adhesive on the surface of the material.

Solids content is an important property and can be understood as that part of the adhesive that forms the glue line, since after evaporation of the liquid components, "curing" or adhesive polymerization occurs, forming the glue line, which is responsible for the bond between substrates and for the transfer of tensions generated in the wood - glue - wood system. High solids content contributes to the quality of the glue line, due to the greater amount of solid material, improving the adhesion between the wood and the adhesive. The ideal range to maintain good material quality is around 40 to $45 \%$ [36]. Some studies have shown that it is possible to work with solid content for tannin-based adhesive with values of 40 to $55 \%$. MORI, et al. [29] studied values of $55 \%$ for mixtures of adhesives and tannins removed from the bark of the black wattle; In the present study, it was observed that the Eucalyptus grandis tannins were significantly different from those obtained with other species. 
The working time of an adhesive refers lifespan of the adhesive after its preparation, until the gel phase, when it reaches the maximum viscosity. It was found that the tannin-based adhesive had a working time of more than 30 minutes, as well as phenol formaldehyde. The proportions between the tannin and the hardener (formaldehyde) determine the stiffness or elasticity of the glue line formed and will facilitate or hinder the spread of the adhesive in the wood. High amounts of tannin lead to a more rigid glue line, while an excess of formaldehyde results in a more elastic glue line. This fact is directly linked to the gel time of the adhesive, i.e., the feasibility of working with the adhesive, prior to its polymerization or cure.

The results show that the tannin extracted from the coconut mesocarp has the potential to be used as an adhesive agent in the production line, compared to phenol formaldehyde.

Mixtures of phenol-formaldehyde with tannin were made in three different proportions in order to analyze whether tannins mixed with phenol formaldehyde improve their qualitative characteristics as an adhesive. Table 4 presents values of the adhesives properties.

It was observed that as the proportion of tannin increases in the mixtures, $\mathrm{pH}$ value reduces, which is desirable in an adhesive since a positive result, since a $\mathrm{pH}$ above 11 interferes negatively in the mechanical properties of the panels, accelerating the degradation of the fibers.

Table 4: Phenol formaldehyde adhesive properties in different concentrations with coconut mesocarp tannin.

\begin{tabular}{l|c|c|c}
\hline \multirow{2}{*}{ PROPERTIES } & \multicolumn{3}{|c}{ CONCENTRATION (\%): PHENOL + TANNIN SOLUTION } \\
\cline { 2 - 4 } & $\mathbf{9 0 / 1 0}$ & $\mathbf{8 0 ~ / ~ 2 0}$ & $\mathbf{7 0 / 3 0}$ \\
\hline $\mathrm{pH}$ & 12.08 & 11.28 & 10.87 \\
Viscosity (cp) & 240.67 & 286.87 & 237.36 \\
Gel time (min) & 30.00 & 6.92 & 3.32 \\
\hline
\end{tabular}

Viscosity is one of the most important factors, since a high viscosity will make it difficult to spread the adhesive on the surface of the wood. The viscosity of the solution was very uniform, even though there was variation in its concentration in the mixture. The values are within optimum range, which should be below $1500 \mathrm{cp}$, maximum value for use as a manufacturing adhesive of wood panels [36].

Gel time provides important information about adhesive cure; it can hinder or facilitate the panel making process, influencing the formation of glue line. One of the major limitations in the use of tannin-based adhesive is the high reactivity of the tannins with the binding agent, thus forming a very fast curing adhesive [29]. The gel time has undergone many variations. There is a high difference in gel time values from the 80:20 and 70:30 mixtures, evidencing that the addition of mesocarp tannin greatly accelerated the reaction.

\section{CONCLUSIONS}

- The mesocarp of the green coconut is a material with potential for the extraction of tannin and for the manufacture of composites;

- $5 \%$ sodium sulphite presented better yield in tannic extraction;

- When compared with synthetic adhesives, the coconut tannic extracts presented values that meet adhesive standards up until $50 \%$ solution;

- The bands observed in the FTIR spectrum of the green coconut mesocarp are characteristic of tannins found in biomass, presenting desirable chemical characteristics to be used as adhesive.

\section{BIBLIOGRAFY}

[1] PIZZI, A., MITTAL, K. L., Handbook of adhesive technology, New York: Marcel Dekker, 1994.

[2] SANTANA, M. A. E., PASTORE JÚNIOR, F., Adesivo de tanino-formaldeído para aglomerados, Brasília, DF, IBDF, 1995.

[3] GULER, H, ZUH, H., OZKAN, H. E., et al., "Spray characteristics and drift reduction potenteal with air induction and conventional flat-tan nozzles", Transactions of the ASAB, v. 50, n. 3, pp. 745-754, 2007.

[4] SENHORAS, E. M., "Oportunidade na cadeia agroindustrial do coco-verde: Do coco nada se perde, tudo se desfruta”, Revista Urutágua, n. 5, pp. 08-11, 2004. 
[5] SÓCRATES, G., Infrared characteristic group frequencies, 2 ed., Chichester, Wiley. 1994.

[6] OWEN, N. L., THOMAS D. W., "Infrared studies of "hard" and "soft" Woods", Applied Spectroscopy, v. 43, n. 3, pp. 451-455, 1989.

[7] FERREIRA, E. S., LELIS, R. C. C., BRITO, E. O., et al., "Teores de taninos da casca de quatro espécies de pinus", Floresta e Ambiente, v. 16, n. 2, pp. 30-39, 2009.

[8] WISSING, A., "The utilization of bark II: investigation of the Stiasny-reaction for the precipitation of polyphenols in Pine bark extractives", Svensk Papperstidning, v. 58, n. 20, pp. 745-750, 1955.

[9] ASTM, D. 1200-94, "Standard Test Method for Viscosity by Ford Viscosity Cup", In: American Society for Testing and Materials, pp. 103-105, 1994.

[10] BRITO, E. O., Produção de chapas de partículas de madeira a partir de maravalhas de Pinus elliottii Engelm. var. elliottii plantado no sul do Brasil, Tese de D.Sc., Universidade Federal do Paraná, Curitiba, PR, Brasil, 1995.

[11] XU, F., YU, J., TESSO, T., DOWELL. F., et al., "Qualitative and quantitative analysis of lignocellulosic biomass using infrared techniques: A mini-review", Applied energy, v. 104, pp. 801-809, 2013.

[12] CARVALHO, M. Z., Abordagem multivariada do comportamento das propriedades físico-quimicas e caracterização de adesivos naturais à base de taninos, Tese de D.Sc., Universidade Federal de Lavras, Lavras, MG, Brasil, 2016.

[13] PING, L., PIZZI, A., DING GUO, Z., et al., "Condensed tannins from grape pomace: Characterization by FTIR and MALDI TOF and production of environment friendly wood adhesive", Industrial Crops and Products. n. 40, pp. 13-20, 2012.

[14] FERNANDEZ, K., AGOSIN, E., "Quantitative analysis of red wine tannins using Fourier transform mid-infrared spectrometry", Newspaper Agricultural Food Chemistry, v. 55, n. 18, pp. 7294-7300, 2007.

[15] LEE, Y. H., "Dyeing, fastness, and deodorizing properties of cotton, silk, and wool fabrics dyed with coffee sludge (Coffea arabica L.) extract", Journal of applied polymer science, v. 103, n. 1, pp. 251-257, 2007.

[16] KIM S, KIM H. J., "Curing behavior and viscoelastic properties of pine and wattle tannin-based adhesives studied by dynamic mechanical thermal analysis and FTIR-ATR spectroscopy", Journal of adhesion science and technology, v. 17, n. 10, pp. 1369-1383, 2003.

[17] MURUGANANTHAN, M., BHASKAR, R. G., PRABHAKAR, S., "Removal of tannins and polyhydroxy phenols by electro-chemical techniques", Journal of chemical technology and biotechnology, v. 80, n. 10, pp. 1188-1197, 2005.

[18] PARDESHI, S., DHODAPKAR, R., KUMAR, A., "Quantum chemical density functional theory studies on the molecular structure and vibrational spectra of Gallic acid imprinted polymers", Spectrochimica Acta Part A: Molecular and Biomolecular Spectroscopy, v. 116, pp. 562-573, 2013.

[19] DIMITRIC-MARKOVIC, J. M., MIOC, U. B., BARANAC, J. M., et al., "A study of the IR spectra of the copigments of malvin chloride with organic acids", Journal of the Serbian Chemical Society, v.66, p. 7, pp. 451-462, 2001.

[20] ARANGUREN, M. I., BORRAJO, J., WILLIAMS, R. J. J., "Some aspects of curing novolac with hexamethylenetetramine", Journal of Polymer Science Part A: Polymer Chemistry, v. 20, n. 2, pp. 311-318. 1982.

[21] GRISHECHKO, L. I., AMARAL-LABA, G., SZCZUREKA, A., et al., "New tannin-lignin aerogels", Industrial Crops and Products, v. 41, pp. 347-355, 2013.

[22] KANNAN, R. R. R., ARUMUGAM, R., ANANTHARAMAN, P., "Transform infrared spectroscopy analysis of seagrass polyphenols", Current Bioactive Compounds, v. 7, n. 2, pp. 118-125, 2011.

[23] PUICÃ, N. M., PUI, A., FLORESCU, M., "FTIR spectroscopy for the analysis of vegetable tanned ancient leather", European Journal of Science and Theology, v. 2, n. 4, p. 49-53, 2006

[24] COATES, J. "Interpretation of infrared spectra, a practical approach". Encyclopedia of Analytical Chemistry, pp. 10815- 10837, 2006.

[25] CARNEIRO, A. C. O., VITAL, B. R., PIMENTA, A. S., et al., "Reatividade dos taninos da casca de Eucalyptus grandis para produção de adesivos", Cerne, v.7, n.1, pp. 001-009, 2001.

[26] RICCI, A., OLEJAR, K., PARPINELLO, G., et al., "Application of Fourier Transform Infrared (FTIR) Spectroscopy in the Characterization of Tannins", Applied Spectroscopy Reviews, v. 50, n. 5, pp. 407-442, 
2015.

[27] VIEIRA, M. C., LELIS, R. C. C., RODRIGUES, N. D., "Propriedades químicas de extratos tânicos da casca de Pinus oocarpa e avaliação de seu emprego como adesivo", Cerne, v. 20, n. 1, pp. 47-54, 2014.

[28] PIZZI, A. Wood adhesives: chemistry and technology, New York: Marcel Dekker, 1983.

[29] MORI, F. A., VITAL, B. R., PIMENTA, A. S., et al., "Análise cinética da cura de adesivos de taninos das cascas de três espécies de eucalyptus por calorimetria diferencial exploratória (DSC) ", Revista Árvore, v. 26, n. 4, pp. 493-497, 2002.

[30] GONÇALVES, F. G., LELIS, R. C. C., OLIVEIRA, J. T. S., "Influência da composição da resina tanino-uréia-formaldeído nas propriedades físicas e mecânicas de chapas aglomeradas", Revista Árvore, v. 32, n .4, pp.715-722, 2008.

[31] BRÍGIDA, A. I. S., MORSYLEIDE, F. R., "Determinação do Teor de Taninos na Casca de Coco Verde (Cocos nucifera L) ", In: Proceedings of the Interamerican Society for Tropical Horticulture. v. 47, pp. 2527, 2003.

[32] CARVALHO, A. G., LELIS, R. C. C., NASCIMENTO, A. M., "Avaliação de adesivos à base de taninos de Pinus caribaea var. bahamensis e de Acacia mearnsii na fabricação de painéis aglomerado", Ciências Florestais, v. 24, n. 2, pp. 479-489, abr.-jun., 2014.

[33] VITAL, B. R., CARNEIRO, C. O., A., PIMENTA, A. P., et al., "Adesivos à base de taninos das cascas de duas espécies de eucalipto para produção de chapas de flocos", Revista Árvore, v. 28, n. 4, pp. 571-582, 2004.

[34] ALMEIDA, N. F., MORI, F. A., GOULART, S. L., et al., "Estudo da reatividade de taninos de folhas e cascas de barbatimão Stryphnodendron adstringens (Mart.) Coville", Scientia Forestalis, v. 38, n. 87, p. 401408, 2010

[35] ROFFAEL, E., DIX, B. “Tannine als Bindemittel für Holzwerkstoffe”, Holz-Zentralblatt, v. 120, n. 6, pp. 90-93, 1994.

[36] IWAKIRI, S., KEINERT J. R., MENDES, L. M., "Painéis de madeira compensada". In: Iwakiri, S. Painéis de madeira reconstituída, Curitiba, PR, FUPEF. 2005.

[37] MACIEL, A. S., ANDRADE, A. M., ALBUQUERQUE, C. E. C., "Procedimentos para a extração e utilização de fenóis de alcatrão na produção de adesivos fenólicos", Floresta e Ambiente, v. 3, n. 1, pp. 86-95, 1996.

\section{ORCID}

Fernanda Lago Morbeck

Roberto Carlos Costa Lelis

Maria Vanessa Egger Schueler

Wanessa Aparecida Santos

Danielle Affonso Sampaio

Bruno Couto da Silva

Rayssa de Medeiros Morais

Gregório Mateus Santana https://orcid.org/0000-0002-5262-1154

https://orcid.org/0000-0003-2923-3839

https://orcid.org/0000-0002-3968-402X

https://orcid.org/0000-0002-6283-6888

https://orcid.org/0000-0003-3625-6086

https://orcid.org/0000-0002-7670-9628

https://orcid.org/0000-0003-4384-4134

http://orcid.org/0000-0003-4682-6513 